[Regular Paper]

\title{
Reference Material for Calibration of Sulfur in Liquid Fuels at Trace Level
}

\author{
Yuko KITAMAKI* and Kenji KATO \\ National Metrology Institute of Japan, National Institute of Advanced Industrial Science and Technology, \\ 1-1-1 Umezono, Tsukuba, Ibaraki 305-8563, JAPAN
}

(Received September 5, 2011)

\begin{abstract}
Sulfur reference material for the calibration of sulfur in liquid fuels at trace level, NMIJ RM 4216-a, have been issued by National Metrology Institute of Japan, National Institute of Advanced Industrial Science and Technology (NMIJ, AIST). Toluene was selected for the candidate reference material. The sulfur reference value of this reference material was determined by analysis of the candidate reference material in ampules. The sulfur reference value is $19 \mu \mathrm{g} \cdot \mathrm{kg}^{-1}$ and the expanded uncertainty $(k=2)$ is $5 \mu \mathrm{g} \cdot \mathrm{kg}^{-1}$. The measurement of trace sulfur in the sample was performed using the combustion followed by the ultraviolet fluorescence method. The standard addition method based on the precise gravimetric mixing was applied in the determination.
\end{abstract}

\section{Keywords}

Trace level, Sulfur, Reference material, Fuel, Quality control

\section{1. 緒言}

近年は，産業・環境などの分野において，微量硫黄分を精確 に測定することが求められている。そのため, 分析機器の発展, 特に高感度化や高精度化には非常にめざましいものがある。こ のような機器の進歩に伴い, 実際に分析を行う際には, 様々な 機器のなかから, 分析目的に合った機器を適切に選定して測定 を行うことができる場面が多くなってきている。

液体燃料中の硫黄に関して, 現在日本では自動車燃料中の硫 黄分に対して, $10 \mathrm{ppm}$ 以下（サルファーフリー）の規制が設 けられている1)。液体燃料中の硫黄分を測定するには, 電量滴 定法 ${ }^{2)}$, 蛍光 X 線法 ${ }^{3)}$, 紫外蛍光法, イオンクロマトグラフィー4) などがあり，分析対象試料のマトリクス性状や濃度，また測定 操作の簡便さなどを考慮して分析方法を選択することができ る。一方, これらの分析機器は濃度目盛の校正をする必要があ る。校正を適切に行うためには，標準物質を使用する。

液体燃料中の硫黄分を測定するための認証標準物質は, 既に いくつかの機関から様々なマトリクスや硫黄濃度のものが供給 されている。サルファーフリーに対応する標準物質 $(10 \mathrm{mg}$. $\mathrm{kg}^{-1}$ 以下）を挙げると, 国外の標準研究機関からは, 米国国立 標準技術研究所（NIST）から NIST SRM 2298（(4.7 $\pm 1.3 ） \mathrm{mg}$. $\left.\mathrm{kg}^{-1}\right)$ ， NIST SRM $1616 \mathrm{~b}\left((8.41 \pm 0.12) \mathrm{mg} \cdot \mathrm{kg}^{-1}\right)$ ，また EU 標準 物質·計測研究所 (IRMM) から ERM-EF213 $((9.1 \pm 0.8) \mathrm{mg}$. $\mathrm{kg}^{-1}$ ) が供給されている。国内では，(社)石油学会から S0526

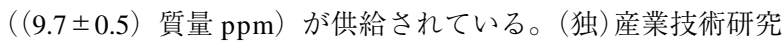
所 計量標準総合センター（NMIJ, AIST）からは, 機器校正用 標準液として，NMIJ CRM 4215-a $\left((0.98 \pm 0.02) \mathrm{mg} \cdot \mathrm{kg}^{-1}\right)^{5)}$ お

\footnotetext{
* To whom correspondence should be addressed.

* E-mail: y-kitamaki@aist.go.jp
}

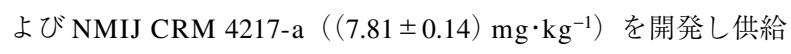
を行っている。

一方, クリーンエネルギーとして注目されている燃料電池の 使用においては, 燃料電池用燃料を製造するための触媒に対し て, 硫黄が触媒毒となる。そのため, 触媒性能を十分に発揮さ せるためにトレースレベルでの脱硫技術の開発が進められてい る。しかし, 触媒性能評価を適切に行うためのトレースレベル $\left(0.1 \mathrm{mg} \cdot \mathrm{kg}^{-1}\right.$ 以下) $)$ 硫黄標準物質の供給はなかった。そこで NMIJ では, トレースレベルの硫黄標準液, NMIJ RM 4216-a の 開発に着手した。

またKellyらは，2種類の NIST SRM を用いて，分析者が望 む濃度の標準液を分析者が調製する方法を提案しているの。 2 種類の NIST SRM を質量比で精確に混合調製することにより， 機器の校正や検量線の作成に必要な標準液を NISTトレーサブ ルに調製できる。2種類の認証標準物質を混合して低濃度の標 準液を調製する場合, 硫黄の認証值が高い標準物質と硫黄分が 十分低い標準物質を用意する必要がある。今回開発した NMIJ RM 4216-a は, 硫黄分の参考值が $(19 \pm 5) \mu \mathrm{g} \cdot \mathrm{kg}^{-1}$ と極めて低 い標準液であるため, トレースレベルの硫黄標準液を調製する 際の希釈溶媒としても使用することができる。

\section{2. 実}

\section{験}

\section{1. 值付け方法}

認証標準物質の值付けには, 参照標準を必要としない絶対測 定法 (一次標準測定法) の採用が推奨されており, 前述した NIST SRM 2298, NIST SRM 1616b や ERM-EF213 の值付けには, 一次標準測定法の一つである同位体希釈質量分析法 (IDMS 法) が用いられている。IDMS 法は複雑なマトリクス試料中の微量

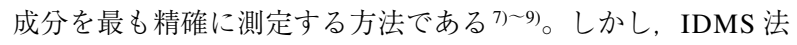
は複雑な試料前処理操作を必要とし, 測定ブランクが大きく, 
トレースレベルの硫黄を精確に值付けするのは困難である。近 年, Barker らは, バイオディーセルおよびディーゼル燃料中の 硫黄分析について, 蛍光 X 線法を用いた標準添加法による評 価法について検討した ${ }^{10)}$ 。蛍光 X 線法は測定試料マトリクス の炭素/水素比が硫黄の検出応答に大きく影響する。そのため, 標準液と実試料のマトリクスが大きく異なると, 硫黄の定量值 にバイアスがかかるために精確な定量が難しい。しかし，標準 添加法を用いることにより，マトリクス効果をキャンセルした 測定が可能となる。IDMS 法で評価した $\mathrm{mg} \cdot \mathrm{kg}^{-1} レ$ レルの認証 標準物質（NIST SRM 2723a, ERM-EF674a）について, 蛍光 X 線法による標準添加法で定量した結果は，IDMS 法による認証 值の拡張不確かさの範囲内でよく一致していた。このことは, 標準添加試料の調製を質量比で精確に行うことで, 一次標準測 定法と同様の適切な定量值が得られることを示している。

そこでNMIJでは, NMIJ RM 4216-a の開発にあたり, 試料 調製を質量比で行う標準添加法を用いて值付けを行うことにし た。しかし，トレースレベルの測定においては，蛍光X線法 では感度が十分ではない。そこで, より高感度な測定方法であ る紫外蛍光法を用いることにした。

\section{2. 候補標準の選定および調製}

日本では，液体燃料中の硫黄分析において，硫黄標準液を調 製するときの希釈溶媒にトルエンがよく使用されていることか ら，NMIJ RM 4216-a の候補標準にはトルエンを選定した。 NMIJ RM 4216-a は, 市販品として入手可能なトルエン中に含 まれる硫黄分に対して精確に值付けしたものである。

市販のトルエン中に含まれる硫黄分は，同じ試薬グレードで も, 試薬の生産ロットによって数 $\mu \mathrm{g} \cdot \mathrm{kg}^{-1} \sim$ 数十 $\mu \mathrm{g} \cdot \mathrm{kg}^{-1}$ 程度 と大きく異なる。そこで，候補標準を選定するにあたり，数種 類の市販トルエンを入手して燃焼-紫外蛍光法による評価を 行った。得られたピーク面積を比較し, シグナルが最も低かっ たトルエンを候補標準とした。選定した高純度トルエン（分光 分析用) は関東化学(株)により,アルゴン雾囲気下において 350 本の茶褐色アンプル瓶に $30 \mathrm{~mL}$ ずつ小分けされた。

\section{3. 試薬および装置}

標準添加試料の調製において, 添加する標準液としては NMIJ CRM 4215-a を使用した。燃焼 - 紫外蛍光法における硫黄 化合物形態の違いによる值付けへの影響を検討するために，添 加する標準液として NIST SRM 2298 を用いた分析も行った。

硫黄分の分析には，微量硫黄分析計 TS-100V（(株)三菱化学 アナリテック製）を用いた。なお，トレースレベルの硫黄を検
出するために濃縮ユニットである TRU-100（(株)三菱化学アナ リテック製) を TS-100V の燃焼管下流に接続した。キャリヤー ガスは，液化アルゴンを気化させたアルゴンおよび酸素 （>99.5\%）をパイプラインで供給しているものを使用した。 燃焼に関する測定条件は，キャリヤーガス流量（アルゴン： $250 \mathrm{~mL} \cdot \mathrm{min}^{-1}$, 酸素 : $150 \mathrm{~mL} \cdot \mathrm{min}^{-1}$ ), 補助ガス流量（試料燃焼 中は酸素 : $400 \mathrm{~mL} \cdot \mathrm{min}^{-1}$, 試料を燃焼していないときはアルゴ ン : $50 \mathrm{~mL} \cdot \mathrm{min}^{-1}$ ), 燃焼管温度 (上部 : $900{ }^{\circ} \mathrm{C}$, 下部 : $1000{ }^{\circ} \mathrm{C}$ ), 試料注入量 : $250 \mu \mathrm{L}$, 試料注入速度 : $1.2 \mu \mathrm{L} \cdot \mathrm{s}^{-1}$ である。濃縮工 ニットは, 試料を注入し始めてからトラップ温度 $200{ }^{\circ} \mathrm{C}$ で生 成ガスをトラップさせた。トラップ時間は $400 \mathrm{~s}$ (試料をすべ て燃焼させ濃縮させるに十分な時間）である。その後, $800{ }^{\circ} \mathrm{C}$ に上昇させて紫外蛍光検出器で測定した。

標準添加試料を質量比混合法にて精確に調製するために，化 学天秤 XS205（メトラー・トレド製）を使用した。この天秤の 校正は，計量法校正事業者登録制度（JCSS）により行った。

\section{3. 結 果}

\section{1. 均質性試験}

アンプル詰めされた NMIJ RM4216-a 中の硫黄分に対して均 質性試験を行った。均質性試験は，小分けされた 350 本のアン プルの中から，ランダムに10本を抜き取って行った。ただし 10 本のうちには, アンプル溶封順で最初と最後の 2 本を含めて いる。各アンプル中の試料は, 測定バイアル 5 本に約 $5 \mathrm{~mL}$ つ採取した。計 50 本の測定バイアル中の試料は, 燃焼 - 紫外 蛍光法にて各 1 回ずつ測定した。なお測定順は, アンプル溶封 順ではなく, ランダムに行った。測定結果を Table 1 に示す。 評価は ISO Guide 35 に従い, 得られたピーク面積を用いて分散 分析を行い，測定の精度を含めたアンプル間変動 $u_{\text {ba }}$ を算出し た ${ }^{11)}$ 。その結果, 均質性に伴う相対不確かさは $2.11 \%$ と求め られた。

\section{2. 調製ばらつき評価}

SI 単位にトレーサブルな標準物質の值付け方法の一つに質 量比混合法がある。標準ガスや無機標準液などの一次標準物質 は質量比で調製される場合が多い。しかし，トルエンなどの有 機溶媒は揮発性が高いため, 一般的に安定して秤量することは 難しい。そこで, 秤量中に扔ける試料の揮発による調製濃度の 変化を防ぐために, 調製容器はアルミシールバイアルとミニ ナートバルブ（GL Science）を使用した。ミニナートバルブを 用いることにより，揮発性の高い有機溶媒も精確に秤量するこ

Table 1 Homogeneity Study of NMIJ RM 4216-a

\begin{tabular}{|c|c|c|c|c|c|c|c|c|c|c|}
\hline Ampule No. & 1 & 66 & 108 & 151 & 185 & 216 & 250 & 289 & 330 & 363 \\
\hline \multirow[t]{5}{*}{ Peak area } & $3770477^{a)}$ & 2345272 & 2440703 & 2257802 & 2020941 & 1988882 & 1955316 & 1840724 & 1783092 & 1754021 \\
\hline & 2101198 & 1853097 & 2448178 & 1910672 & 1934686 & 1819355 & 2143010 & 1766994 & 2060443 & 2013545 \\
\hline & 2263414 & 2254479 & 1937760 & 1973139 & 2233724 & 2233517 & 2490838 & 2559052 & 2451767 & 2083629 \\
\hline & 2019763 & 2010317 & 2135470 & 2013421 & 2246896 & 2056942 & 2113482 & 2134002 & 2253868 & 2139469 \\
\hline & 2457970 & 2183348 & 2136230 & 1922840 & 2192758 & 2141022 & 1946952 & 2119540 & 2166896 & 2251521 \\
\hline Average & 2210586 & 2129303 & 2219668 & 2015575 & 2125801 & 2045944 & 2129920 & 2084062 & 2143213 & 2048437 \\
\hline SD & 193536 & 197281 & 220566 & 141495 & 139924 & 154347 & 220606 & 311895 & 247259 & 186190 \\
\hline
\end{tabular}

a) This measurement result was rejected by the Grubbs outlier test. 
とができる ${ }^{12)}$ ○しし，試料調製には，秤量精度だけでなく調 製時に扔ける調製操作の精度（調製ばらつき）も評価する必要 がある。

調製ばらつきを見積もるために，硫黄分が約 $50 \mu \mathrm{g} \cdot \mathrm{kg}^{-1} に な$ るように，測定試料を同一日に 3 回独立に調製し，紫外蛍光法 で測定した。調製方法は, 風袋（ミニナートバルブを取り付け たアルミシールバイアル）を秤量した後，ガスタイトシリンジ でトルエン (和光純薬工業(株)，インフィニティピュアグレー ド）約 $20 \mathrm{~mL}$ を注入し秤量した。トルエンを入れた秤量值から 風袋の秤量值を差し引くことで, トルエンの採取量を求めた。 その後, 別のガスタイトシリンジで NMIJ CRM 4215-a 約 $1 \mathrm{~mL}$ を注入し秤量した。NMIJ CRM 4215-a を入れた秤量值から卜 ルエンを入れたときの秤量值を差し引くことで, NMIJ CRM4215-a の精確な採取量を求めた。なお，秤量時の気温と 湿度を記録し，浮力補正に用いた。

得られたピーク面積 $A_{\text {meas }}$ は，Eq. (1)に示すように独立に調 製した各試料の調製濃度 $C_{x}$ で規格化し，規格化ピーク面積 $A_{\text {norm }}$ に変換した。調製ばらつきは，規格化ピーク面積 $A_{\text {norm }}$ を 分散分析して求めた。

$$
A_{\text {norm }}=\frac{A_{\text {meas }}}{C_{x}} \times 50
$$

分散分析の結果, 調製に伴う相対不確かさは $1.58 \%$ と評価し た。

\section{3. 特性値および不確かさの算出}

\subsection{1. 測定バックグラウンドの評価}

值付けは標準添加法で行った。標準添加法はマトリクス効果 をキャンセルできるという利点がある一方, 微量分析の場合に おいては，測定中のバックグラウンドを適切に評価し補正する 必要が生じる。本開発において, 使用した微量硫黄分析計は卜 レースレベルの硫黄を測定することが可能である。しかし，試 料を導入しないで測定を行った時も，硫黄のピークがわずかに 見られたため, これを測定バックグラウンドとして補正した。

濃縮ユニットを取り付けた紫外蛍光法の場合に考えられる測 定バックグラウンドには，キャリヤーガス中の不純物，装置内 の材質やコンタミネーションに起因するものが考えられる。こ の測定バックグラウンドについて, NMIJ CRM 4215-a の開発 時に，トラップ時間（400１200 s） が長くなるほどバックグ ラウンドシグナルが直線的に増大することを報告した5)。すな わち，装置内を流れるキャリヤーガス量が多くなるほど，キャ リヤーガス中の不純物や装置内のコンタミネーション成分など が濃縮ユニット内で濃縮されるために, 測定バックグラウンド として現れると推察した。

装置内でのコンタミネーションが主な測定バックグラウンド 要因であると仮定すると，装置を稼働させ続ければ，装置内が 徐々にクリーンアップされ，測定バックグラウンドは低減され ると考えた。そこで，測定バックグラウンドを連続50回（約 15 時間）測定し，バックグラウンドシグナルの経時変化につ いて検討した。

測定は，測定前にあらかじめ装置を立ち上げ，燃焼炉の温度 およびガス流量を測定開始直前の状態で約 3 時間放置した後で 行った。クリーンアップとして, 試料を注入しない条件をつく るために，オートサンプラーから試料採取用のガスタイトシリ

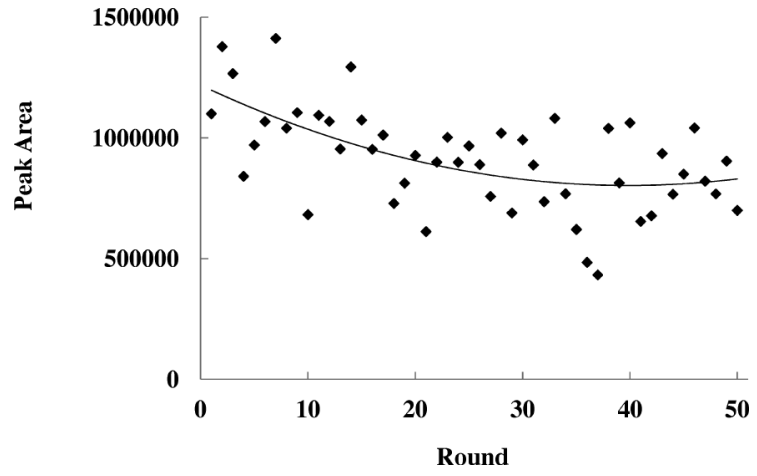

Fig. 1 Effect of the Measurement Time on Background Signal

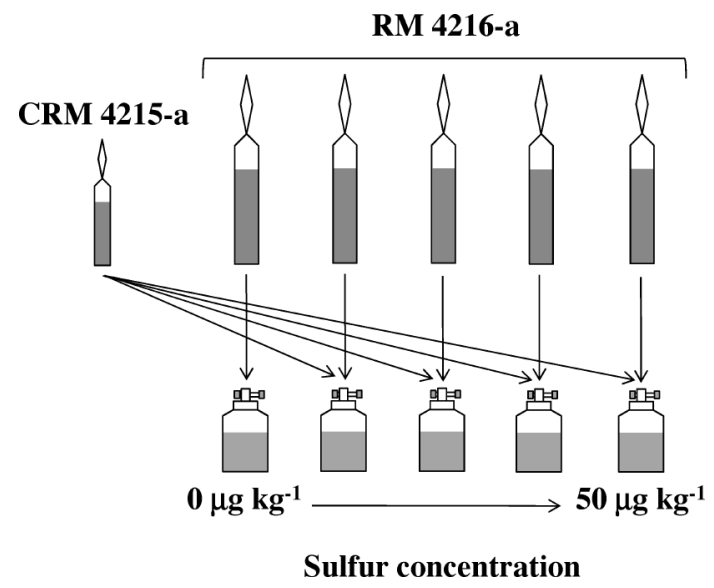

Fig. 2 Preparation Scheme of Standard Addition Samples for the Determination of Sulfur in NMIJ RM 4216-a

ンジを取り外して測定を行った。結果を Fig. 1に示す。測定を 開始して約 30 回目（約 10 時間）までは, わずかではあるが徐々 にシグナル值が減少する傾向が見られたが, それ以降は減少傾 向は見られなくなった。この結果から, あらかじめ装置内を半 日から一日程度十分にクリーンアップしておけば, 測定中は常 に一定のバックグラウンドが現れると考えられた。よって, NMIJ RM 4216-a の值付けおよび不確かさ評価においては, バッ クグラウンドを測定し実験的に評価して，その結果を補正する ことにした。ただし, 装置内のクリーンアップに要する時間は, 測定履歴によっては，もっと多くの時間をかける必要がある場 合もあると考えられる。

\subsection{2. 特性値の決定および不確かさ算出}

特性值を標準添加法で決定するにあたり, 測定試料は, NMIJ RM 4216-a に添加する標準液として NMIJ CRM 4215-a を 用いて調製した。調製した試料濃度は添加量ゼロを含めて4, 5点である。調製スキームを Fig. 2 に示す。調製方法は 3.2.で 述ベたように，ミニナートバルブ付アルミシールバイアルを用 いて行い, 秤量時の気温と湿度を記録し浮力補正に用いた。 NMIJ RM 4216-a の採取量は約 20 mL, CRM 4215-a の採取量は 0〜1 $\mathrm{mL}$ である。

質量比混合法で調製した標準液の硫黄濃度とピーク面積の関 係は直線回帰である。 


$$
Y=b x+a
$$

ここで， $x$ は調製した標準液の硫黄濃度（試料中に元々含まれ ている硫黄分は除く)，Yは得られたピーク面積， $a$ は $Y$ 切片， $b$ は回帰線の傾きである。標準添加法では, 得られるピーク面 積は, 試料中に元々含まれている分析対象成分由来のシグナル と添加した標準由来のシグナルで構成されていることが理想的 である。しかし今回のように，測定バックグラウンドがある場 合は，補正を行う必要がある。そこで，3.3.1.で述べたように， 值付けのための測定を行う前にあらかじめ, 測定バックグラウ ンドを評価し，その結果を以下のように補正することにした。

測定で得られたピーク面積 $Y$ は, NMIJ RM 4216-a に元々含 まれている硫黄のシグナル $y_{\text {toluene, }}$ 添加された硫黄のシグナル $y_{\text {spike }}$ ，および測定バックグラウンドシグナル $y_{\mathrm{bk}}$ の合計である。

$$
Y=y_{\text {toluene }}+y_{\text {spike }}+y_{\text {bk }}
$$

Eq. (2)と Eq. (3)より, 測定試料中の硫黄によるシグナルは,

$$
y_{\text {toluene }}+y_{\text {spike }}=b x+a-y_{\mathrm{bk}}
$$

である。よって, NMIJ RM 4216-a 中の硫黄分 $x_{\mathrm{s}}$ は, （ $y_{\text {toluene }}+$ $\left.y_{\text {spike }}\right)=0$ のとき $x$ 值として, Eq. (4)のようにバックグラウン ドを補正して算出される。

$$
x_{\mathrm{s}}=\frac{\left|a-y_{\mathrm{bk}}\right|}{b}
$$

Fig. 3 に, NMIJ RM 4216-a 中の硫黄を測定した結果を示す。 また, Table 2 に定量值の不確かさ $u\left(x_{\mathrm{s}}\right)$ のバジェット表を示す。 Table 2 に示すように, 定量值の不確かさ $u\left(x_{\mathrm{s}}\right)$ は, 回帰線から 得られる定量值の不確かさ13) と $y_{\mathrm{bk}}$ の測定ばらつきを合成して

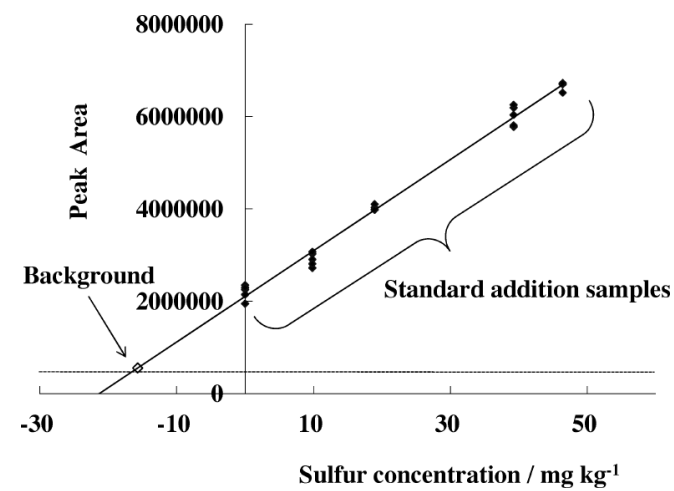

The dotted line is the analyzer background. Sulfur concentration of samples are 0 to $50 \mu \mathrm{g} \cdot \mathrm{kg}^{-1}$.

Fig. 3 The Determination of Sulfur in NMIJ RM 4216-a
算出した。上記の操作による NMIJ RM 4216-a 中の硫黄の定量 は, 測定日を変えて, 独立に 3 回行った。結果を Table 3 に示す。 以上の測定結果から, 硫黄分の特性値は 3 回の定量結果の平均 として $19 \mu \mathrm{g} \cdot \mathrm{kg}^{-1}$ と決定した。

3 回の定量結果の平均によって求めた NMIJ RM 4216-a 中の 硫黄分の測定不確かさは, 測定值の平均の不確かさと各測定の 不確かさを合成して求めた。測定值の平均の不確かさ $u(\bar{x})$ は, ISO Guide 35 を参考に以下のように求めた ${ }^{11)}$ 。測定值の平均の 標準偏差 $s$ は,

$$
\begin{aligned}
& s=\sqrt{\frac{\sum_{n=1}^{3}\left(x_{\mathrm{s}, n}-\bar{x}\right)^{2}}{n-1}}=2.84 \\
& u\left(\bar{x}_{\mathrm{s}}\right)=\frac{s}{\sqrt{n}}=1.64
\end{aligned}
$$

よって, 3 回の測定結果による測定値の不確かさ $u$ は Eq. (7)の 式を用いて算出した。

$$
u=\sqrt{\frac{\sum_{n=1}^{3} u^{2}\left(x_{\mathrm{s}, n}\right)}{n^{2}}+u^{2}\left(\bar{x}_{\mathrm{s}}\right)}=2.16
$$

NMIJ RM 4216-a の主な不確かさ要因は，均質性，調製ばら つき, 添加した標準液 NMIJ CRM 4215-a 中の硫黄分, 定量の 不確かさであるとし，特性值の不確かさの見積もりを行った。 不確かさのバジェット表を Table 4 に示す。Table 4より, 相 対拡張不確かさ $(k=2)$ は $0.24(24 \%)$ と見積もられたため, 特性值の拡張不確かさは, $19 \mu \mathrm{g} \cdot \mathrm{kg}^{-1} \times 0.24=5 \mu \mathrm{g} \cdot \mathrm{kg}^{-1}$ と決定 した。

\section{4. 硫黄化合物形態の違いによる値付けへの影響}

NMIJ RM 4216-a の值付けに用いた添加標準液は NMIJ CRM 4215-aである。これは硫黄化合物としてチオフェンを用い, 卜 ルエンに添加した標準液である。そのため, 今回検討した值付 け方法に执いて, チオフェン以外の硫黄化合物を添加する標準 液として用いても，定量值へ影響しないことを検討した。添加 する標準液にはNIST SRM 2298 を使用した。NIST SRM 2298 の硫黄分認証值はNMIJ CRM 4215-a に最も近い。そのため, 調製から測定におけるすべての過程において，值付け時と同様

Table 3 Sulfur Determination in RM 4216-a by the Standard Addition Method

\begin{tabular}{ccc}
\hline$n$ & $x_{\mathrm{s}, n}\left[\mu \mathrm{g} \cdot \mathrm{kg}^{-1}\right]$ & $u\left(x_{\mathrm{s}, n}\right)\left[\mu \mathrm{g} \cdot \mathrm{kg}^{-1}\right]$ \\
\hline 1 & 15.7 & 1.5 \\
2 & 20.2 & 3.8 \\
3 & 20.9 & 1.1 \\
\hline Properly value & 18.9 & 2.16 \\
\hline
\end{tabular}

Table 2 Uncertainty Budget of the Measurement Value

\begin{tabular}{lccccc}
\hline \multicolumn{1}{c}{ Source of uncertainty } & Value $x_{i}$ & Standard uncertainty $u\left(x_{i}\right)$ & Unit & $c_{i}\left(=\partial f / \partial x_{i}\right)$ & $\left|c_{i}\right| u\left(x_{i}\right)$ \\
\hline Measurement & 15.65 & $1.36^{\mathrm{a})}$ & $\mu \mathrm{g} \cdot \mathrm{kg}^{-1}$ & 1 & 1.36 \\
Background signal & 556363 & 58108.8 & & $1 / b$ & $5.88 \times 10^{-1}$ \\
\hline Combined standard uncertainty & 15.7 & & $\mu \mathrm{g} \cdot \mathrm{kg}^{-1}$ & & 1.5 \\
\hline
\end{tabular}

a) The standard uncertainty of measurement was estimated by using Eq. (5.10) in Ref. 13. 
Table 4 Estimation of the Uncertainty Budget of RM 4216-a

\begin{tabular}{lccl}
\hline \multicolumn{1}{c}{ Source of uncertainty } & Relative standard uncertainty & $c_{i}$ & $\left|c_{i}\right| u\left(x_{i}\right)$ \\
\hline Homogeneity & 0.0211 & 1 & 0.0211 \\
Preparation variation & 0.0158 & 1 & 0.0158 \\
CRM 4215-a (starting material) & $0.01^{\text {a) }}$ & -1 & 0.01 \\
Measurement of sulfur in RM 4216-a & $0.014^{\text {b) }}$ & 1 & 0.014 \\
\hline Relative combined standard uncertainty & & 0.12 \\
Relative expanded uncertainty (the coverage factor; $k=2)$ & 0.24 \\
\hline
\end{tabular}

a) The certified value of CRM $4215-\mathrm{a}$ is $(0.98 \pm 0.02) \mathrm{mg} \cdot \mathrm{kg}^{-1}$ (the coverage factor is $\left.k=2\right)$. Therefore, standard uncertainty is $0.01 \mathrm{mg} \cdot \mathrm{kg}^{-1}$.

b) In the Table 3, the standard uncertainty of the properly value of NMIJ RM 4216-a is estimated

$2.16 \mu \mathrm{g} \cdot \mathrm{kg}^{-1}$. The relative standard uncertainty to the properly value can be estimated 0.114 .

の操作で NMIJ RM 4216-a 中の硫黄分の評価を行うことができ る。また, NIST SRM 2298 は, ハイオクタンガソリン中に含ま れる硫黄分を IDMS 法で值付けした標準物質であり，硫黄分に 関して精確に值付けされている一方，含まれている硫黄化合物 形態に関する情報はない。しかしながら，マトリクスがガソリ ンであることから, チオフェンと同程度に揮発性の高い硫黄化 合物が含まれていると推測された。NIST SRM 2298 を添加する 標準液として用いて候補標準を測定した結果, NMIJ RM 4216-a 中の硫黄分は $(19 \pm 9) \mu \mathrm{g} \cdot \mathrm{kg}^{-1}$ と評価された。NIST SRM 2298 を添加標準液として用いた結果の拡張不確かさが大 きい理由は, NIST SRM 2298 の認証值の不確かさが NMIJ CRM 4215-a よりも大きいこと，㧍よび検討実験時の測定ばらつきが 大きかったことが要因である。それでも，定量值は NMIJ CRM 4215-a を添加標準液に使用して得られた特性值と同程度の結果 となった。見積もられた拡張不確かさが大きいために断定する ことはできないが, 標準添加法で值付けを行う際に, 添加標準 液と実試料の性状が大きく異ならなければ，添加標準液中に含 まれる硫黄化合物形態の違いによる影響は, 本標準液の值付け において，大きな影響はなかった。つまり，本值付けにおいて は, 添加標準液として硫黄化合物をチオフェンで代表しても影 響はないと推測した。

\section{4. 結 論}

硫黄分析におけるトレースレベルの校正に利用可能な標準液 NMIJ RM 4216-a を開発した。NMIJ RM 4216-a の参考值は, 燃 焼-紫外蛍光法を用いた標準添加法による分析で決定した。卜 ルエン中のトレースレベルの硫黄分を分析するために，濃縮工 ニットを燃焼管下流に接続した。これにより，トルエン中の硫 黄分を測定できる。一方で, 測定バックグラウンドの補正が必 要となった。装置内を十分にクリーンアップした後，バックグ ラウンドシグナルを測定前にあらかじめ評価して，值付けの際 の補正に使用した。

今回考案した評価方法において, 適切に評価された高濃度の 硫黄標準液を添加する標準として用い, 質量比で適切に調製を 行えば，燃焼-紫外蛍光法で測定を行う際には，硫黄化合物形 態の違いによる影響は評価した拡張不確かさの範囲内では見ら
れなかった。

NMIJ RM 4216-a は, (独) 産業技術総合研究所 計量標準総合 センター（NMIJ, AIST）から2009年より頒布されている。参 考值は $(19 \pm 5) \mu \mathrm{g} \cdot \mathrm{kg}^{-1}$ である。NMIJ RM 4216-a を用いるこ とによって, トレースレベルの硫黄分を測定する際の機器校正 をすることができる。また, NMIJ CRM 4215-a, NMIJ CRM 4217-a など, より高い濃度の硫黄標準液と組み合わせることに よって, $1 \mathrm{mg} \cdot \mathrm{kg}^{-1}$ 以下のレベルの標準液を調製する際の希瀵 溶媒としても利用することができる。

\section{References}

1) Petroleum Association of Japan, http://www.paj.gr.jp/index. html.

2) White, D. C., Anal. Chem., 49, 1615 (1977).

3) Miskolczi, N., Bartha, L., Antal, F., Dudas, C., Talanta, 66, 1264 (2005).

4) Andrew, M., Burholt, I. M. V., Kernoghan, N. J., Lynch, T. P., Mackison, R., Mealor, D., Price, J. A., Schofield, P., J. Chromatogr., 640, 111 (1993).

5) Kitamaki, Y., Shimizu, Y., Kato, K., Anal. Bioanal. Chem., 391, 2089 (2008).

6) Kelly, W. R., MacDonald, B. S., Leigh, S. D., J. ASTM Int., 4, 2 (2007).

7) Kelly, W. R., Vocke Jr., R. D., Mann, J. L., Turk, G. C., Metrologia, 44, 08008 (2007).

8) Kelly, W. R., Paulsen, P. J., Murphy, K. E., Vocke Jr., R. D., Chen, L. T., Anal. Chem., 66, 2505 (1994).

9) Hearn, R., Berglund, M., Ostermann, M., Pusticek, N., Taylor, P., Anal. Chim. Acta, 532, 55 (2005).

10) Barker, L. R., Kelly, W. R., Guthrie, W. F., Energy \& Fuels, 22, 2488 (2008).

11) JIS Q 0035, "Reference materials - General and statistical principles for certification," Japanese Standards Association, Tokyo (2008).

JIS Q 0035, “標準物質一認証のための一般的及び統計的 な原則, ”日本規格協会, 東京 (2008).

12) Ueno, H., THE CHEMICAL TIMES, No. 1, 3 (2003).

13) Miller, J. N., Miller, J. C., "Statistics and chemometrics for analytical chemistry," Kyoritsu Shuppan Co., Ltd., Tokyo (2006), p. 142.

Miller, J. N., Miller, J. C., “データのとり方とまとめ方一 分析化学のための統計学とケモメトリックス (第2版), 共立出版, 東京 (2006), p. 142. 
要旨

\title{
液体燃料中のトレースレベル硫黄分分析用標準液の開発
}

\author{
北牧 祐子, 加藤 健次
}

(独) 產業技術総合研究所 計測標準研究部門, 305-8563 茨城県つくば市梅園1-1-1つくば中央第3事業所

（独）産業技術総合研究所 計量標準総合センター（NMIJ， ンを用い，硫黄分の参考值は，アンプル詰めした侯補標準を分 AIST）では, トレースレベルの硫黄分を精確に測定するため 析して值付けした。硫黄分の参考值は $19 \mu \mathrm{g} \cdot \mathrm{kg}^{-1}$, 拡張不確か の校正用標準液, NMIJ RM 4216-a を開発した。開発した標準さは $5 \mu \mathrm{g} \cdot \mathrm{kg}^{-1} \quad(k=2)$ である。測定には, 燃焼-紫外蛍光法を 液は，液体燃料中のトレースレベルの硫黄分を測定するときの 採用し，トルエン中の硫黄分の決定は標準添加法で行った。

機器校正用として使用できる。標準液の原料には高純度トルエ 